\title{
Analisis cadangan devisa Indonesia dan faktor-faktor yang mempengaruhinya
}

\author{
Pundy Sayoga*; Syamsurijal Tan
}

Prodi Ekonomi Pembangunan, Fakultas Ekonomi dan Bisnis, Universitas Jambi

*E-mail korespondensi:pundi_sayoga@yahoo.com

\begin{abstract}
This study aims to analyze the factors that influence Indonesian coffee exports. The data in this study is time series data, which were obtained from various government agencies. The Error Correction Model (ECM) method is used to analyze the effect of coffee prices, GDP and the exchange rate on the volume of Indonesian coffee exports. The estimation results find that coffee prices, Indonesian GDP and exchange rates have a short-term relationship and a long-term balance of the volume of coffee exports. Based on the long-term estimation of the coffee price variable, GDP and exchange rates do not significantly affect the volume of coffee exports, while in the short term these three variables influence the volume of coffee exports.
\end{abstract}

Keywords: Error Correction Model, Coffee exports, coffee prices, exchange rates.

\begin{abstract}
Abstrak
Penelitian ini bertujuan untuk menganalisis perkembangan cadangan devisa Indonesia dan faktor-faktor yang mempengaruhi cadangan devisa Indonesia. Data yang digunakan adalah data sekunder yang berasal dari Badan Pusat Statistik dan Bank Indonesia. penelitian ini menggunakan dua analisis yaitu analisis deskriptif dan analisis kuantitatif. Analisis tersebut digunakan untuk melihat faktor-faktor apa saja yang dapat mempengaruhi cadangan devisa Indonesia. Berdasarkan hasil regresi diketahui bahwa utang luar negeri dan nilai ekspor berpengaruh positif dan signifikan terhadap cadangan devisa Indonesia sedangkan kurs rupiah berpengaruh negatif dan signifikan terhadap cadangan devisa Indonesia.
\end{abstract}

Kata kunci : Cadangan Devisa, Utang Luar Negeri, Nilai Ekspor, Kurs

\section{PENDAHULUAN}

Perkembangan pembangunan ekonomi Indonesia dewasa ini menunjukkan semakin terintergrasi dengan perekonomian dunia.Hal ini merupakan konsekuensi dari dianutnya sistem perekonomian terbuka yang dalam aktivasinya selalu berhubungan dan tidak lepas dari fenomena hubungan internasional.Perdagangan internasional merupakan salah satu aspek penting dalam perekonomian setiap negara di dunia. Perdagangan atau pertukaran dapat diartikan sebagai proses tukar menukar yang didasarkan atas kehendak sukarela dari masing-masing pihak. Masing-masing pihak harus mempunyai kebebasan untuk menentukan untung rugi dari pertukaran tersebut, dari sudut kepentingan masingmasing kemudian menentukan apakah ia mau melakukan pertukaran atau tidak (Budiono, 1982). Dalam melakukan perdagangan internasional maka setiap negara memerlukan cadangan devisa sebagai alat pembayaran luar negeri. Dalam sejarah teori perdagangan internasional, paham Merkantilisme yang memperkenalkan bahwa devisa adalah emas (gold). Bahkan emas merupakan lambang kekayaan suatu negara, sehingga kebijakan pemerintah harus menciptakan surplus emas, karena emas sebagai alat pembayaran internasional. Emas diciptakan melalui surplus ekspor, yang akan 
menghasilkan negara yang makin kuat. Dengan demikian perencanaan ekonomi berorientasi memperbesar ekspor dan memperkecil impor dengan target memperbanyak emas. Tujuan penggunaan devisa antara lain untuk membiayai kegiatan perdagangan luar negeri, Membayar barang-barang impor, membayar cicilan dan bunga pinjaman luar negeri. Cadangan devisa merupakan indikator moneter yang sangat penting yang menunjukkan kuat atau lemahnya fundamental perekonomian suatu negara. Selain itu, cadangan devisa dalam jumlah yang cukup merupakan salah satu jaminan tercapainya stabilitas moneter dan perekonomian makro suatu negara (Tambunan, 2001). Besar kecilnya posisi cadangan devisa suatu negara tergantung pada berbagai macam faktor yang berpengaruh pada masing-masing unsur dalam neraca pembayaran Indonesia.

Bagi negara berkembang seperti Indonesia ekspor memegang peranan penting dalam pembangunan nasional, valuta asing yang didapat dari kegiatan ekspor akan menambah cadangan devisa negara yang pada akhirnya dapat memperkuat fundamental perekonomian Indonesia. Salah satu upaya pemerintah untuk mendapatkan devisa dari luar negeri dengan jalan melakukan pinjaman ke negara lain dan mengekspor hasilhasil sumber daya alam ke luar negeri. Dari hasil devisa ini maka dapat digunakan untuk menambah dana pembangunan negara.

Berdasarkan data dari badan pusat statistik, cadangan devisa Indonesiadi tahun 2013 berada di angka US\$ 99.387Juta, angka ini menunjukan penurunan yang cukup tajam dimana pada tahun sebelumnya posisi cadangan devisa menunjukan angka tertinggi selama sepuluh tahun terakhir. Kemudian pada tahun 2014posisi cadangan devisa naik $12 \%$ dari tahun sebelumnya menjadi sebesar US\$ 111.861 Juta. Dan pada tahun 2015 posisi cadangan devisa kembali turun 5\% dengan nilai US\$105.931 Juta.

Penurunan cadangan devisa yang terus menerus dapat membahayakan perekonomian suatu negara, kelangkaan cadangan devisa menyebabkan tidak memungkinkannya mengimpor barang-barang modal dalam upaya pembangunan. Sumber keuangan dari luar (baik hibah maupun pinjaman) dapat memainkan peranan penting dalam usaha melengkapi kekurangan sumber daya yang berupa devisa ataupun tabungan domestik, sehingga dengan adanya aliran modal dari luar akan mempengaruhi cadangan devisa. Nilai hutang luar negeri Indonesia secara keseluruhan pada tahun 2013 mencapai US\$266.109 juta.Kemudian pada tahun 2014 total hutang luar negeri mengalami peningkatan sebesar 1\% dengan nilai US\$269,300 Juta. Dan pada tahun 2015 peningkatan yang cukup pesat terjadi pada total hutang luar negeri sebesar $15 \%$ dengan nilai US\$ 310,700 Juta.

Sementara nilai ekspor selama periode 2013-2015 menunjukkan penurunan dimana pada tahun 2013 nilai eksporIndonesia senilai US\$ 182,551 Juta, selanjutnya pada tahun 2014 turun sebesar 3\% dengan nilai US\$176,980 Juta. Dan pada tahun 2015 nilai ekspor kembali turun sebesar 15\% dibandingkan dengan tahun sebelumnya sebesar US\$ 150,366 Juta.Nilai kurs Rupiah terhadap US\$ sepanjang tahun 2013-2015 juga secara terus menerus mengalami depresiasi. Pada tahun 2013 nilai kurs rupiah terhadap US Dollar senilai Rp 12.189 per dollar, pada tahun 2014 nilai kurs rupiah terhadap US dollar sebesar Rp12.440, dan pada tahun 2015 kurs rupiah terhadap dollar sebesar Rp13.796 per dollar.

Berdasarkan latar belakang tersebut, penelitian ini bertujuan untuk menganalisis pengaruh nilai ekpor, utang luar negeri, dan kurs rupiah terhadap perkembangan cadangan devisa Indonesia tahun 2000-2015.

\section{METODE PENELITIAN}

Data yang digunakan dalam penelitian ini adalah data sekunder dalam bentuk runtun waktu (time series) periode 2000 sampai dengan 2015.Data diperoleh dari Badan Pusat Statistik (BPS), Bank Indonesia (BI). Data terdiri dari: 
1. Data nilai ekspor Indonesia

2. Data utang luar negeri Indonesia.

3. Data nilai tukar rupiah terhadap US dollar.

4. Data cadangan devisa Indonesia.

Prosedur yang dipakai dalam pengumpulan data didasarkan pada pencarian, pemilihan, pencatatan dan pengkategorian data yang diperlukan dan dilakukan perhitungan sesuai dengan kategori data yang diperlukan.Beberapa variabel tersedia dan langsung dapat digunakan untuk pengolahan, sebagian lainnya memerlukan perhitungan lebih lanjut.

Metode analisis deskriptif digunakan untuk mengetahui dan menjelaskan perkembangan dan pertumbuhan, ekspor,utang luar negeri, nilai tukar dan cadangan devisa Indonesia selama periode 2000 hingga 2015. Selanjutnya alat analisis regresi berganda digunakan menganalisis faktor-faktor yang mempengaruhi cadangan devisa Indonesia dengan menggunakan model persamaan sebagai berikut:

Dimana:

$$
\log C D=\beta 0+\beta_{1} \log X_{t}+\beta_{2} \log \mathrm{HLN}_{t}+\beta_{3} \log \mathrm{NT}_{\mathrm{t}}+\mathrm{e}
$$

CD : Cadangan devisa Indonesia

$\beta 0 \quad$ : Konstanta

$\beta_{1}, \beta_{2}, \beta_{3}$ : Koefisien regresi

$\mathrm{X}$ : Nilai ekspor

HLN : Utang luar negeri

NT : Nilai tukar rupiah terhadap US dollar

$\mathrm{t} \quad$ : Tahun tertentu

e : Eror term.

\section{HASIL DAN PEMBAHASAN}

Rata-rata cadangan devisa Indonesia selama periode 2000-2015 sebesar US\$ 65.646 juta dengan rata-rata pertumbuhan 10,1\%. Cadangan devisa Indonesia tertinggi terjadi pada tahun 2012 dengan nilai sebesar US\$ 112.781 Juta dan perkembangan tertinggi terjadi pada tahun 2010 dengan perkembangan sebesar 45,53\%. Sementara cadangan devisa terendah terjadi pada tahun 2001 sebesar US\$28.016 Juta dan perkembangan terendah terjadi pada tahun 2013 dengan pertumbuhan lebih kecil 11,87 \% dibandingkan dengan tahun sebelumnya.

Terdapat berbagai faktor yang mempengaruhi cadangan devisa Indonesia. Berdasarkan estimasi model untuk faktor utama yang mempengaruhinya, diberikan sebagai berikut:

\begin{tabular}{lllll}
\hline \hline Variable & Coefficient & Std. Error & t-Statistic & Prob. \\
\hline \hline C & -1.328458 & 0.727163 & -1.826906 & 0.0927 \\
HLN (Log) & 0.977929 & 0.185505 & 5.271721 & 0.0002 \\
KURS (Log) & -0.548922 & 0.248757 & -2.206663 & 0.0476 \\
X (Log) & 0.626372 & 0.103706 & 6.039857 & 0.0001 \\
\hline \hline
\end{tabular}




\begin{tabular}{llll} 
R-squared & 0.974060 & Mean dependent var & 4.759255 \\
Adjusted R-squared & 0.967574 & S.D. dependent var & 0.234257 \\
S.E. of regression & 0.042183 & Akaike info criterion & -3.281286 \\
Sum squared resid & 0.021353 & Schwarz criterion & -3.088139 \\
Log likelihood & 30.25029 & Hannan-Quinn criter. & -3.271395 \\
F-statistic & 150.1991 & Durbin-Watson stat & 2.024225 \\
Prob(F-statistic) & 0.000000 & & \\
\hline \hline
\end{tabular}

Secara simultan seluruh variabel dalam model (hutang luar negeri, nilai tukar rupiah dan ekspor) berpengaruh signifikan terhadap cadangan devisa Indonesia. Hal ini terlihat dari nilai $F$ statitic sebesar 150,1991 dengan prob (F-statistic) $=0,000<0,01$. Berdasarkan nilai Adjusted R-squared dapat dinyatakan bahwa kontribusi seluruh variabel sebesar 96,76 persen terhadap pergerakan/variasi cadangan devisa Indonesia.

Dari hasil perhitungan diperoleh koefisien hutang luar negeri sebesar 0.977929, nilai t-hitung 5.271721, probabilita t-hitung sebesar $0,0002<0,01$. Ini menunjukkan bahwa terdapat pengaruh positif yang signifikan hutang luar negeri terhadap cadangan devisa Indonesia. Setiap peningkatan $1 \%$ hutang luar negeri akan meningkatkan cadangan devisa sebesar $0.977929 \%$.

Koefisien kurs sebesar -0.548922 , nilai t-hitung -2.206663 , probabilita t-hitung sebesar $0.0476<0,05$. Ini menunjukkan bahwa terdapat pengaruh negatif yang signifikan dari kurs terhadap cadangan devisa Indonesia. Setiap peningkatan $1 \%$ nilai kurs akan menurunkan cadangan devisa sebesar $0.548922 \%$.

Koefisien ekspor sebesar 0.626372, nilai t-hitung 6.039857, probabilita t-hitung sebesar $0.0001<0,01$. Ini menunjukkan bahwa terdapat pengaruh positif yang signifikan dari ekspor terhadap cadangan devisa Indonesia. Setiap peningkatan $1 \%$ ekspor akan meningkatkan cadangan devisa sebesar $0.626372 \%$.

\section{PENUTUP}

Dari analisis yang telah dibahas dalam penelitian ini, maka dapat ditarik kesimpulan :

1. Berdasarkan analisis deskriptif perkembangan cadangan devisa rata-rata selama periode 2000-2015 adalah sebesar 10,09 \%. Perkembangan cadangan devisa tertinggi terjadi pada tahun 2010 yaitu sebesar 45,53\% dengan nilai 96.207 Juta US dollar. Sementara perkembangan cadangan devisa terendah terjadi pada tahun 2011 sebesar $-11,87 \%$ dengan nilai 110.123 Juta US dollar.

2. Berdasarkan hasil regresi diperoleh bahwa :

a. Secara simultan, utang luar negeri, nilai ekspor, dan kurs rupiah secara bersama-sama mempunyai pengaruh yang signifikan terhadap perubahan cadangan devisa Indonesia periode 2000-2015.

b. Utang luar negeri mempengaruhi cadangan devisa secara signifikan. Dimana utang luar negeri mempunyai hubungan positif terhadap cadangan devisa selama periode $2000-2015$. 
c. Nilai ekspor mempengaruhi cadangan devisa secara signifikan. Dimana nilai ekspor mempunyai hubungan positif terhadap cadangan devisa selama periode 2000-2015.

d. Kurs rupiah terhadap US dollar mempengaruhi cadangan devisa secara signifikan. Dimana kurs berpengaruh negatif terhadap cadangan devisa selama periode 2000-2015.

\section{DAFTAR PUSTAKA}

Amir.M.S.1999. Ekspor-Impor Teori dan Penerapannya, PT Pustaka Binaman Presindo : Jakarta.

Anonim, Laporan Perekonomian Indonesia, Berbagai Edisi, BPS.

Anonim, Pengelolaan Cadangan Devisa di Bank Indonesia, BI.

Astanti, Ayu. 2015. Analisis Kausalitas Antara Utang Luar Negeri Dan Pertumbuhan Ekonomi Di Indonesia Tahun 1990-2013.

Badan Pusat Statistik, Statistik 70 Tahun Indonesia Merdeka. Jakarta : BPS

Budiman, Arief. 1999. Teori Pembangunan Dunia Ketiga. Gramedia Pustaka. Jakarta

Benny, Jimmi (2014). "Ekspor Dan Impor Pengaruhnya Terhadap Posisi Cadangan

Devisa Di Indonesia”. Junal Emba. Vol.1 no.4. hal 1406-1415.

Ojs.unud.ac.id/index.php/eep/article/viewfile/6679/5325. 24 januari 2017

Boediono,1982.Teori Pertumbuhan Ekonomi,BPFE,Yogyakarta.

Dumairy. 1997. Perekonomian Indonesia. Erlangga. Jakarta

Haryadi, 1997. Hutang Luar Negeri Indonesia dan Langkah-langkah Pengendaliannya, Buletin Ekonomi FE-UNJA Jambi

Junaidi, J. (2014). Regresi dengan Microsoft Office Excel. Jambi. Fakultas Ekonomi dan Bisnis Universitas Jambi

Junaidi, J. (2014). Analisis Hubungan Deret Waktu untuk Peramalan. Jambi. Fakultas Ekonomi dan Bisnis Universitas Jambi

Kamaluddin,1998.Pengantar Ekonomi Pembangunan, FEUI, Jakarta.

Krugman, R Paul. 1997. Ekonomi Internasional, FEUI, Jakarta.

Latumaerissa, Julius R. 2015. Perekonomian Indonesia dan Dinamika Ekonomi Global.Mitra Wacana Media . Jakarta

Mankiw. N, Gregory. 2006. Pengantar Makroekonomi. Edisi Ketiga. Salemba Empat. Jakarta.

Pinem, Juniarta R. 2009. "Analisis Pengaruh Ekspor, Impor, Kurs Nilai Tukar Rupiah Terhadap Cadangan Devisa Indonesia. USU

Putra, Ida Bagus Putu Purnama. Februari 2011. "Pengaruh Tingkat Inflasi, Utang Luar Negeri Dan Suku Bunga Kredit Terhadap Cadangan Devisa Indonesia Tahun 1996-2011.

E-Jurnal.

Universitas

Udayana.Ojs.unud.ac.id/index.php/eep/.../5325. 24 Januari 2017

Rachbini,J. Didik dan Tono, Suwidi. 2000. Bank Indonesia : Menuju Independensi Bank Sentral. PT.Mardi Mulyo. Jakarta.

Roger, Scott (1993). Management of Foreign Exchange Reserves, BIS. Basle

Salvator,Dominik. 1990. Ekonomi Internasional. Jilid II.Edisi Kedua. PT. Raja

Grafindo, Jakarta 
Tan, Syamsurijal. 2004. Ekonomi Internasional. Citra Pratama. Jambi.

Tan, Syamsurijal. 2014. Perdagangan Internasional (Teori dan Beberapa Aplikasinya). FE UNJA.

Tambunan, 2000.Perdagangan Internasional dan Neraca Pembayaran : Teori dan Temuan Empiris.LP3ES, Jakarta.

Tambunan.Tulus. 2001. Transformasi Ekonomi di Indonesia. Teori dan Penemuan Empiris. Salmba Empat. Jakarta.

Yunita.Rina.2013. Analisis Pengaruh Nilai Tukar dan Impor Terhadap Cadangan Devisa Indonesia. Universitas Jambi. 